\title{
Soil Loss Estimation for Conservation Planning in the Dolago Watershed Central Sulawesi, Indonesia
}

\author{
Naharuddin Naharuddin ${ }^{1 *}$, Adam Malik', Ahyauddin Ahyauddin ${ }^{2}$ \\ 1 Department of Forestry, Faculty of Forestry, Tadulako University, Central Sulawesi, 94119, Indonesia \\ 2 Department of forestry, Faculty of forestry, Jambi University, Jl. Jambi-Muara Bulian Km. 15 Mendolo Barat, \\ Jambi, Indonesia \\ * Corresponding author's e-mail: naharuddin.sumani@untad.ac.id
}

\begin{abstract}
Soil loss assessment in watersheds is useful in developing plans for the protection and conservation of soil and water in a sustainable manner. This study aimed to determine erosion hazard classification and erosion hazard map using Revised Universal Soil Loss Equation (RUSLE) as the basis of a soil and water conservation planning program. The RUSLE model was used to assess soil loss and guide the soil conservation efforts. Annual rainfall data, digital elevation model (DEM), land use map were used to generate the RUSLE parameters, namely rainfallrunoff erosivity factor (R), soil erodibility factor (K), slope length and steepness factor (LS), cover-management factor $(\mathrm{C})$, and support practices factor $(\mathrm{P})$. Erosion hazard is classified into five classes, namely very low, low, medium, high, and very high. On the basis of the results, at the Dolago watershed, very high erosion hazard was found in dryland of $577.95 \mathrm{t} / \mathrm{ha} / \mathrm{yr}$. Meanwhile, very low erosion hazard was found in the rice field of $2.22 \mathrm{t} / \mathrm{ha} / \mathrm{yr}$. The results help in planning and implementing soil and water conservation, both vegetatively and mechanically, to minimize the damage to watershed ecosystems. Validation and testing of the RUSLE model should be carried out in future studies because this is a strategic step to develop modeling of sediment yields effectively in an effort to mitigate major land damage in watersheds.
\end{abstract}

Keywords: watershed, RUSLE, soil conservation,erosion hazard classification.

\section{INTRODUCTION}

Soil loss is the second largest problem after population growth in the world [Pradhan et al., 2012] and is threatening the watershed ecosystem [Zokaib and Naser, 2011; De Mello et al., 2018; Li et al., 2018; Giacomazzo et al., 2020], agricultural and plantation production [Gomiero, 2016; Tarigan et al., 2018]. Soil loss not only causes agricultural land to be poor in nutrients, but also harms the ecological balance of the watershed and causes poverty for local communities [Sun et al., 2013; Sokouti and Nikkami, 2017]. Approximately $85 \%$ of land degradation in the world was caused by soil loss causing a decrease in yields of 17\% [Siddique et al., 2017].

In Indonesia, watershed degradation is mostly influenced by the soil loss triggered by land use around the watershed that does not use the principles of soil and water conservation [Abood et al., 2015; Harjianto et al., 2016]. Rainfall is the main cause of soil loss and nutrient loss by causing ecological damage to watersheds [Adimassu et al., 2017].

The cause of soil erosion is the interaction between natural phenomena and human disturbance [Borrelli et al., 2017; Panagos et al., 2018; Poesen, 2018; Tesfaye et al., 2018; Haghighi et al., 2021]. The Dolago upstream areas have experienced disturbances due to shifting cultivation, land occupation, and other land-use practices ignoring soil and water conservation. The Dolago watershed is a watershed priority, meaning that it needs to be addressed in development policies, especially the physical conditions of the land and hydrological factors during degradation, where 
during the rainy season there will be floods and silting of the downstream main rivers.

Various studies have applied different models to calculate the soil loss due to water erosion and sediment yield such as Universal Soil Loss Equation (USLE) [Watena et al., 2021], Revised Universal Soil Loss Equation (RUSLE) [Chuenchum et al., 2020], estimation of soil loss using GIS and remote sensing approaches [Gelagay and Minale, 2016]. The application of a particular model generally depends on the scale or spatial characteristics, accessibility, and data efficiency. RUSLE is the most widely used model and has its main advantages in planning future soil conservation [Ganasri and Ramesh, 2016]. RUSLE is the latest version of the USLE model and has been widely applied in many fields, namely agriculture, geography, forestry, and the territorial approach. The RUSLE model estimates the soil loss due to the integration of geospatial technology with low data requirements. Recent advances in Geographical Information Systems (GIS) have enhanced RUSLE to allow monitoring of erosion at various spatial and temporal ranges.

The factor of soil loss is strongly influenced by rainfall as surface runoff, including soil type and land cover. Therefore, variations in soil loss are mainly caused by the changes in rainfall and vegetation cover inhibiting or accelerating the soil loss process [Mohammad and Adam, 2010; Sharma et al., 2011; Alatorre et al., 2012].

The erosion hazard classification calculation using RUSLE is more widely used at the plot scale, but currently, RUSLE has been developed for a larger land area, especially on the watershed scale. Prediction of soil loss and critical land identification for the application of forest and land management in watersheds are the core of the soil and water conservation program [Tesfaye et al., 2018]. RUSLE has been adopted in several countries in the world as an equation of soil loss giving the best results in planning soil and water conservation in a sustainable manner [Kalambukattu and Kumar, 2017; Tessema et al., 2020]. According to Phinzi et al., (2021), RUSLE is an equation that is useful as a guide in the soil and water conservation strategies, both mechanically and vegetatively.

The Dolago upstream area is experiencing environmental degradation, especially of the land and water resources. The factors causing the decline in environmental conditions are the way farmers use land, shifting cultivation, area encroachment, and land occupation, specially protected areas. If it continues, this will increase the high erosion intensively, causing the depletion of topsoil with high organic matter content and making the land less productive and critical.

Ecologically, the Dolago watershed has suffered serious damage, such as a water balance deficit resulting in flooding and drought at any time and the expansion of critical land in the upstream area. In order to carry out conservation planning and appropriate watershed management steps, it is necessary to identify the type of land use with a high soil loss risk. This study aimed to determine the erosion hazard classification and erosion hazard map in the Dolago Watershed Central Sulawesi using RUSLE as the basis of a soil and water conservation planning program.

\section{MATERIAL AND METHODS}

\section{Time and Location}

This study was carried out from March to November 2020 at Dolago Watershed, Parigi Moutong Regency, Central Sulawesi. The Dolago watershed covers an area of 17,649.76 ha and in the forest management area at the local level namely the Forest Management Unit (FMU) Dolago Tanggunung. This is in accordance with the division of forest management units in the Ministerial Decree of Forestry No.79/Menhut-II/2010. The Dolago Watershed is located on 119 $14^{\prime} 13.80^{\prime \prime} \mathrm{E}$ and $120^{\circ} 33^{\prime} 40.03^{\prime \prime} \mathrm{E}$ and $0^{\circ} 42^{\prime} 46.15^{\prime \prime} \mathrm{S}$ and $1^{\circ} 14^{\prime} 12.67^{\prime \prime} \mathrm{S}$ with the highest altitude of $1.876 \mathrm{~m} \mathrm{ASL}$ (Figure 1) and the average elevation of $375 \mathrm{~m}$ ASL. The analysis of soil physical and chemical properties, especially soil erodibility factor $(\mathrm{K})$ was conducted at the Laboratory Faculty of Agriculture and Faculty of Forestry, Tadulako University.

\section{Methods}

The soil loss rate equation was developed by Wischmeier and Smith, (1978) to estimate the annual average soil loss occurring in a watershed. RUSLE is used to calculate the soil loss as a result of six factors namely rainfall-runoff erosivity factor (R), soil erodibility factor (K), slope length and steepness factor (LS), cover-management 


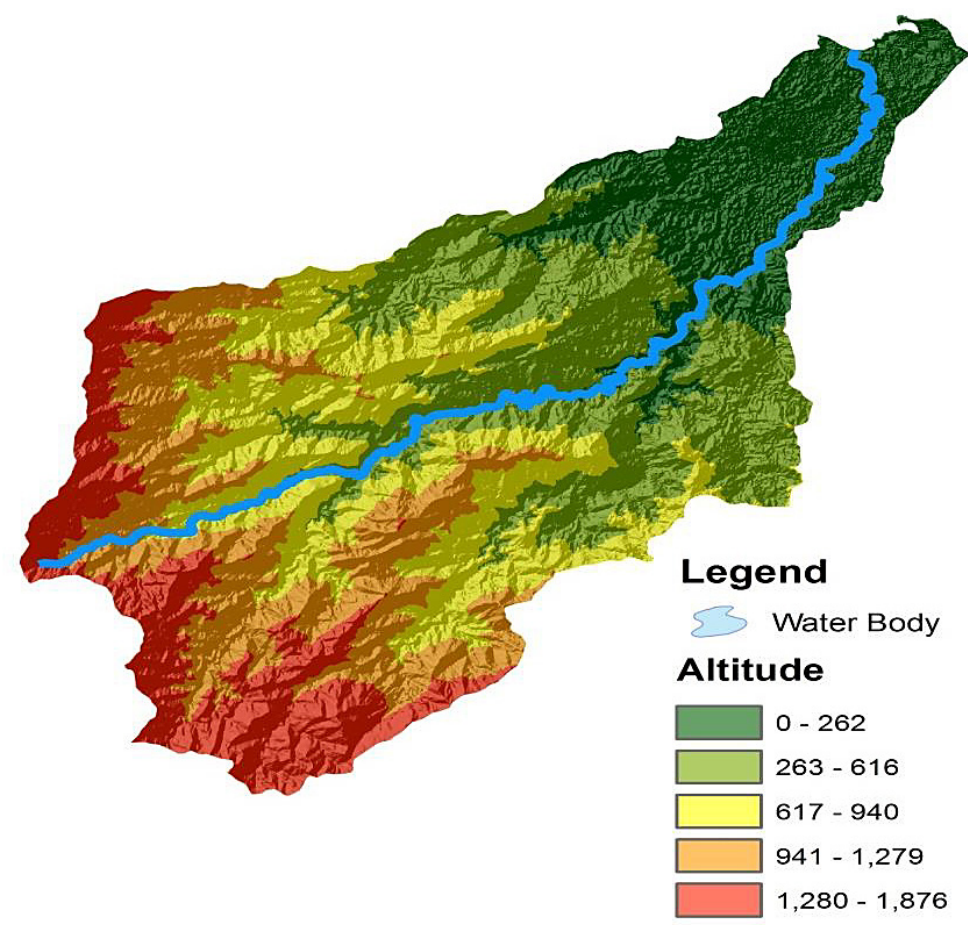

Figure 1. Altitude in Dolago Watershed

factor $(\mathrm{C})$, and support practices factor $(\mathrm{P})$ with the following formula:

$$
\mathrm{A}=\mathrm{R} * \mathrm{~K} * \mathrm{LS} * \mathrm{C} * \mathrm{P}
$$

Rainfall-runoff erosivity factor $(\mathbf{R})$ is a rain kinetic force causing the release of particles from the soil mass including the transport of soil particles to the lowest place [Silalahi et al., 2017]. This study used annual rainfall erosivity data for 10 years (from 2011 to 2020) from the rain gauge station at the Kasiguncu Poso Meteorological Station and was calculated using the following formula:

$$
\mathrm{R}=2.21 \mathrm{MR}^{1.36}
$$

where: $R=$ Rainfall erosivity factor, $M R=$ monthly rainfall.

Soil erodibility factor $(\mathbf{K})$ is the sensitivity of soil to erosion, the higher the soil erodibility, the easier it will be eroded [Silalahi et al., 2017]. Soil erodibility can be calculated by the following formula:

$$
\begin{aligned}
100 \mathrm{~K}= & 1.292(2.1 . \mathrm{M} 1.14(10-4)(12-\mathrm{a})+ \\
& +3.25(\mathrm{~b}-2)+2.5(\mathrm{c}-3)
\end{aligned}
$$

where: $K=$ soil erodibility value,
$M=$ particle size $(\%$ dust $+\%$ very fine sand ) $\mathrm{x}(100-\%$ clay $)$,

$a=$ the organic matter content $(\%)$

$b=$ the soil structure class

$c=$ the permeability class (cm/hour).

In order to obtain the $\mathrm{K}$ value according to Wischmeier and Smith (1978), it is necessary to take soil samples to the study location. The first stage is to observe the soil type map. The map can determine the number of soil samples taken. The Dolago watershed has five types of soil, namely red-yellow podzolic, brown forest soil, lithosol, alluvial, and gray hydromorphous. In this study, each type of soil was collected at two different points. The samples consisting of two types, namely disturbed soil samples and undisturbed soil samples, were taken. The soil samples were obtained using ring samples.

Slope length and steepness factor (LS), is the steeper the slope, the greater the slope value and the easier it will be for the soil to erode. The determination of the slope value was carried out by the presence of slope class data classified based on the slope value (LS) (Table 1).

Soil loss is influenced by slope steepness to a greater extent than by slope length. The higher the soil loss, the higher the steepness is. In the RUSLE model, the effect of topography on soil loss is estimated by a combination of slope length 
(L) and slope steepness (S) as one index expressed as the soil loss ratio [Wischmeier, 1978].

Slope length and steepness (LS) were analyzed using the following formula:

$\mathrm{LS}=\mathrm{L}^{1 / 2}\left(0.00138 \mathrm{~S}^{2}+0.00965 \mathrm{~S}+0.0138\right)$

where: $L=$ Slope length $(\mathrm{m})$,

$S=$ Slope steepness $(\%)$.

Cover-Managment factor (C), is the covermanagement factor represents the soil loss ratio under a certain cover to base soil [Biddoccu et al., 2020]. Land cover with a variety of vegetation life dynamics can reduce soil erosion by slowing runoff and increasing infiltration rates.

If an area has very tight vegetation cover with the cover-management factor $(\mathrm{C})$, the soil will be protected from rainwater, so that high-intensity erosion will not occur. Land use or land cover map is used to estimate the $\mathrm{C}$ value. The land use or land cover map is converted to a vector format and an appropriate $\mathrm{C}$ value is given for each landuse class based on the cover value proposed by Hurni, (1985); Silalahi et al., (2017) (Table 2).

Support Practices factor (P), is the land management with conservation techniques, can make an important contribution in minimizing the rate of soil erosion [Haregeweyn et al., 2015]. In RUSLE, the $\mathrm{P}$ factor is the soil loss ratio with soil conservation practices to the losses associated with cultivation practices on steep slopes with a value of one. The P-value ranges from $0-1$, depending on the soil management activities carried out in a particular plot of soil. This management activity is highly dependent on a slope. The $\mathrm{P}$ factor for cropland and for all other land uses is assumed to be 1 , because there is no practice control measure [Wischmeier and Smith, 1978].

Support practices factor $(\mathrm{P})$ is a land management practice to reduce erosion such as contour farming or terracing on steep slopes with agricultural land, or it can be expressed differently to reduce the runoff rates [Eisenberg and Muvundja,

Table 1. Slope value (LS)

\begin{tabular}{|c|c|c|c|}
\hline Class & Steepness (\%) & Description & LS_Value \\
\hline I & $0-8$ & Flat & 0.40 \\
\hline II & $8-15$ & Sloping & 1.40 \\
\hline III & $15-25$ & Rather steep & 3.10 \\
\hline IV & $25-45$ & Steep & 6.80 \\
\hline V & $>45$ & Very steep & 9.50 \\
\hline
\end{tabular}

2020; Naharuddin et al., 2020]. In order to obtain the $\mathrm{P}$ factor, this study conducted field observations and interviews with farmers utilizing the Dolago watershed. The P factor can be analyzed according to an instruction by Arsyad, (2010) (Table 3).

\section{Data Analysis}

The data processing was carried out on each type of map to obtain the five types of index values required in calculating the erosion hazard index according to Silalahi et al., (2017) (Table 4). The four map types were then overlayed into one combined map showing the area distribution based on the total erosion value of the RUSLE equation for each land cover.

\section{RESULTS AND DISCUSSION}

\section{Rainfall-runoff erosivity (R) factor}

Rainfall erosivity was calculated based on the average monthly and annual rainfall (2011 to 2020) from the Kasiguncu Poso Meteorological rain gauge station. The monthly rainfall erosivity was between 14.113 and 181.115 , the lowest monthly rainfall erosivity was in March while the highest monthly rainfall-runoff erosivity was in August and September. The annual erosivity was 987.605 (Table 5), and meanwhile average monthly rainfall (Figure 2).

The rainfall erosivity factor is an important factor affecting the soil loss in a land use or land cover. Rainfall erosivity is obtained by multiplying the rainfall total kinetic energy with the maximum intensity (30 minutes). In order to minimize erosion in watersheds, infiltration-based

Table 2. Cover management value (C)

\begin{tabular}{|l|c|}
\hline \multicolumn{1}{|c|}{ Land Use } & C_Value \\
\hline Shrubs and natural forests & 0.01 \\
\hline Pasture land & 0.01 \\
\hline Contour farm & 0.14 \\
\hline Mixed agricultural crops & 0.43 \\
\hline Plantation & 0.07 \\
\hline Settlement & 0.20 \\
\hline Rice field & 0.22 \\
\hline Moor or field & 0.50 \\
\hline Vacant land & 0.05 \\
\hline
\end{tabular}


Table 3. Soil conservation practice value (P)

\begin{tabular}{|l|c|}
\hline \multicolumn{1}{|c|}{ Soil conservation practice } & P_Value \\
\hline No erosion control measures & 1.00 \\
\hline Terracing: & 0.04 \\
\hline Good construction & 0.15 \\
\hline Medium construction & 0.35 \\
\hline Poor construction & 0.40 \\
\hline Traditional terracel & \\
\hline Planting strips: & 0.40 \\
\hline Bahia grass & 0.64 \\
\hline Clotararia & 0.20 \\
\hline Contouring & 0.50 \\
\hline Soil preparation and planting according to contours: \\
\hline 0-8\% slope & 0.75 \\
\hline 8-20\% slope & 0.90 \\
\hline$>$ 20\% slope &
\end{tabular}

rainwater management needs to be carried out properly [Asiedu, 2018].

\section{Soil erodibility (K) factor}

Soil erodibility $(\mathrm{K})$ shows the sensitivity of soil to erosion. Soil erodibility is influenced by soil texture (percentage of very fine sand, dust, and clay), soil structure, soil permeability, and soil organic matter content. The analysis of physical and chemical properties was carried out to determine the organic matter, permeability, and soil texture, as presented in Table 6 and Table 7.

On the basis of Table 7, there were two types of land with a very high classification, namely Primary land forest and rice field. Meanwhile, Secondary land forest, dryland farming, and mixed dryland farming were classified as high category, while shrub was included in the Medium category.
Table 4. The commonly used erosion hazard classification in Indonesia

\begin{tabular}{|c|c|c|}
\hline Erosion rate (t/ha/yr) & Class & Erosion Index \\
\hline$<15$ & I & very low \\
\hline $15-60$ & II & low \\
\hline $60-180$ & III & medium \\
\hline $180-480$ & IV & high \\
\hline$>480$ & V & very high \\
\hline
\end{tabular}

\section{Slope length and steepness (LS) factor}

On the basis of the results, (Figure 3), the Dolago watershed has a slope above $40 \%$ (very steep) with an area of 12171.32 ha, $25 \%$ to $40 \%$ (steep) of 2834.19 ha, 15\% to 25\% (Rather steep) of 461.27 ha, and $0 \%-8 \%$ (flat) of 2182.98 ha. The obtained results showed that LS ranged from 0.40 to 9.50 . The lowest LS value was in the rice field, while the highest was in the primary land forest and secondary land forest in the Dolago upstream areas. This is in accordance with the characteristics of the Dolago watershed where the upstream area has a steep to very steep slope class. Slope length and steepness (LS) determines the dimensions and severity of erosion in land use or land cover [Özşahin and Eroğlu, 2019]. Soil loss can increase due to a combination of slope length and steepness in a land unit. The LS factor was obtained from a digital elevation model.

\section{Cover management $(C)$ factor}

The study area has six land cover classes as units of analysis, namely primary land forest, secondary land forest, scrub, dryland agriculture, mixed dryland agriculture, and rice field.

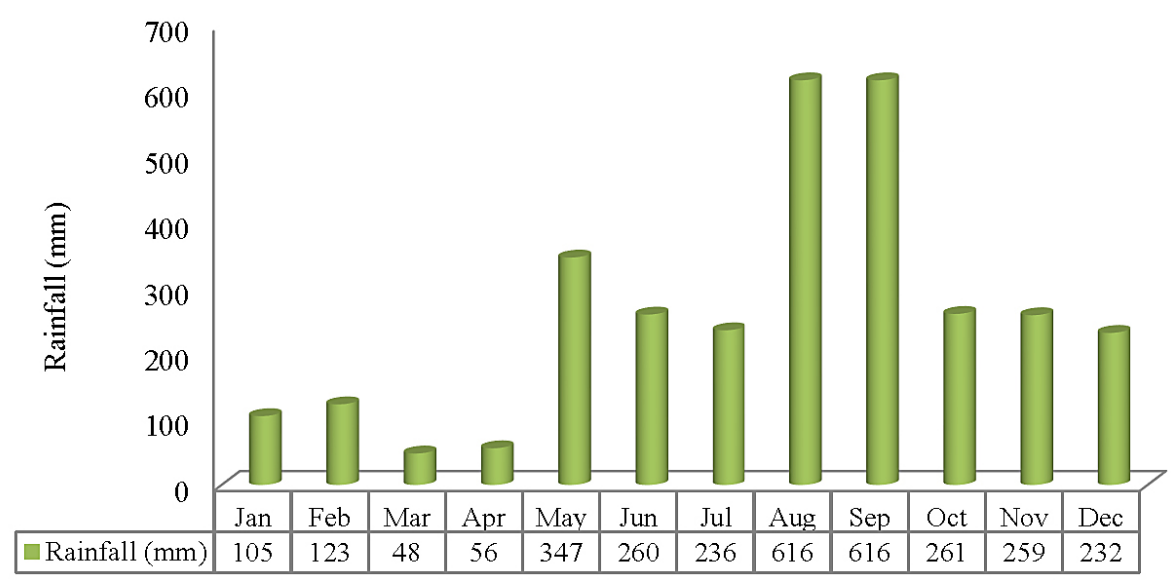

Figure 2. Average monthly rainfall 
Table 5. Rainfall-runoff erosivity factor

\begin{tabular}{|l|c|c|}
\hline \multicolumn{1}{|c|}{ Month } & Monthly rainfall $(\mathrm{cm})$ & $\mathrm{R}=2,21 \mathrm{MR}^{1.36}$ \\
\hline January & 10.5 & 30.872 \\
\hline February & 12.3 & 36.164 \\
\hline March & 4.8 & 14.113 \\
\hline April & 5.6 & 16.465 \\
\hline May & 34.7 & 102.024 \\
\hline June & 26 & 76.445 \\
\hline July & 23.6 & 69.388 \\
\hline August & 61.6 & 181.115 \\
\hline September & 61.6 & 181.115 \\
\hline October & 26.1 & 76.739 \\
\hline November & 25.9 & 134.954 \\
\hline December & 23.2 & 68.212 \\
\hline Rainfall-runoff erosivity & 987.605 \\
\hline
\end{tabular}

Overall, $98.82 \%$ of Dolago watersheds reached $17,649.76$ ha. The $\mathrm{C}$ factor was identified according to land cover (Table 2).

On the basis of the results, the $\mathrm{C}$ factor ranged from 0.01 to 0.43 according to the land use map. In addition, the results showed that the $\mathrm{C}$ factor close to zero was found in forest areas. Meanwhile, a $\mathrm{C}$ factor close to 1 was found in mixed dryland agriculture. The Primary Land Forest had a $\mathrm{C}$ factor of 0.01 so that it can reduce erosion rates. In order to reduce erosion hazards, the forest area needs to be maintained. This is in line with a statement by Teng et al., (2019) that restoring vegetation and maintaining the condition of vegetated forest areas is a promising strategy to reduce the risk of soil loss across various landscapes.

\section{Support Practices (P) factor}

On the basis of the results, the P-factor ranged from 0 to 1 , where, the highest value was found in a land without conservation practices such as dryland farming, while the minimum value was found in the terracing rice fields of 0.04 . Thus, the conservation agriculture system can reduce the erosion rate and increase the efficiency of conservation practices. This is in line with a statement by Mohamed et al., (2013) that these practices can minimize erosion and become an effective input in creating sustainable land use planning and management strategies. According to Chen et al., (2017) and Rybicki, (2021), terracing is considered a soil and water conservation strategy.

\section{Erosion Hazard Classification (EHC)}

The erosion hazard classifictaion was determined based on Table 5. The results showed that erosion hazard classification in the Dolago watershed was in very low to very high category (Figure 4). On the basis of the results, very low erosion hazard was found in rice field of $2.22 \mathrm{t} /$ ha/yr. Meanwhile, Low erosion hazard was found in two types of land namely primary land forest

Table 6. The results of soil physical and chemical properties test

\begin{tabular}{|l|c|c|c|c|c|c|c|}
\hline \multirow{2}{*}{ Land cover } & \multirow{2}{*}{$\begin{array}{c}\text { Organic matter } \\
(\%)\end{array}$} & \multirow{2}{*}{$\begin{array}{c}\text { Permeability } \\
\text { (cm/hour) }\end{array}$} & \multicolumn{4}{c|}{ Texture (\%) } & \multirow{2}{*}{ Texture class } \\
\cline { 6 - 8 } & 2.35 & 1.46 & 41.9 & 31.0 & 23.8 & 3.3 & loamy sand \\
\hline Primary land forest & 1.85 & 5.98 & 47.8 & 28.0 & 18.4 & 5.8 & loamy sand \\
\hline Secondary land forest & 4.78 & 2.32 & 45.9 & 22.2 & 18.2 & 13.7 & sandy loam \\
\hline Shrubs & 3.01 & 2.69 & 46.8 & 27.7 & 21.1 & 4.4 & loamy sand \\
\hline Dryland farming & 2.04 & 3.00 & 36.0 & 31.7 & 21.7 & 10.6 & sandy loam \\
\hline Mixed dryland farming & 2.08 & 1.22 & 20.8 & 42.0 & 25.1 & 12.1 & sandy loam \\
\hline Rice fields & & &
\end{tabular}

Table 7. Soil erodibility calculation

\begin{tabular}{|l|c|c|c|c|c|c|}
\hline \multicolumn{1}{|c|}{ Land cover } & OM & S & P & M & K & Classification \\
\hline Primary land forest & 2.35 & 3 & 5 & 5299 & 0.56 & very high \\
\hline Secondary land forest & 1.85 & 3 & 4 & 4370 & 0.46 & high \\
\hline Shrubs & 4.78 & 3 & 4 & 3486 & 0.28 & medium \\
\hline Dryland farming & 3.01 & 3 & 4 & 4665 & 0.44 & high \\
\hline Mixed dryland farming & 2.04 & 3 & 4 & 4773 & 0.49 & high \\
\hline Rice fields & 2.08 & 3 & 5 & 5898 & 0.64 & very high \\
\hline
\end{tabular}

Description: $\mathrm{OM}=$ the organic matter content $(\%), \mathrm{S}=$ the soil structure class, $\mathrm{P}=$ the permeability class $(\mathrm{cm} /$ hour $)$ $\mathrm{M}=$ soil texture class $(\%$ dust $+\%$ very fine sand $) \times(100-\%$ clay $)$. 
and shrubs of $52.54 \mathrm{t} / \mathrm{ha} / \mathrm{yr}$ and $26.27 \mathrm{t} / \mathrm{ha} / \mathrm{yr}$. Medium erosion hazard was found in secondary land forests namely $86.32 \mathrm{t} / \mathrm{ha} / \mathrm{yr}$, high erosion hazard was found in mixed dryland farming of $291.32 \mathrm{t} / \mathrm{ha} / \mathrm{yr}$. Meanwhile, a very high erosion hazard was found in dryland farming of 577.95 $\mathrm{t} / \mathrm{ha} / \mathrm{yr}$. These results are helpful in understanding the mechanisms behind the soil loss changes based on the dimensions of land use or cover and to provide the information for sustainable soil and water management and vegetation restoration. According to Jin et al., (2021) the changes in land surface conditions, including vegetation cover and forested areas, as well as soil conservation measures have a dominant influence on the spatial heterogeneity of erosion with $11.9 \%$ contributing to erosion reduction. However, the rainfall erosivity factor has a strong effect on increasing soil loss [Abdulkadir et al., 2016]. Likewise, the conversion of forest land from other forms of land use, especially agricultural land, has increased the erosion rate [Zare et al, 2017; Mehri et al., 2018; Ouyang et al., 2018; Naharuddin et al. 2019].

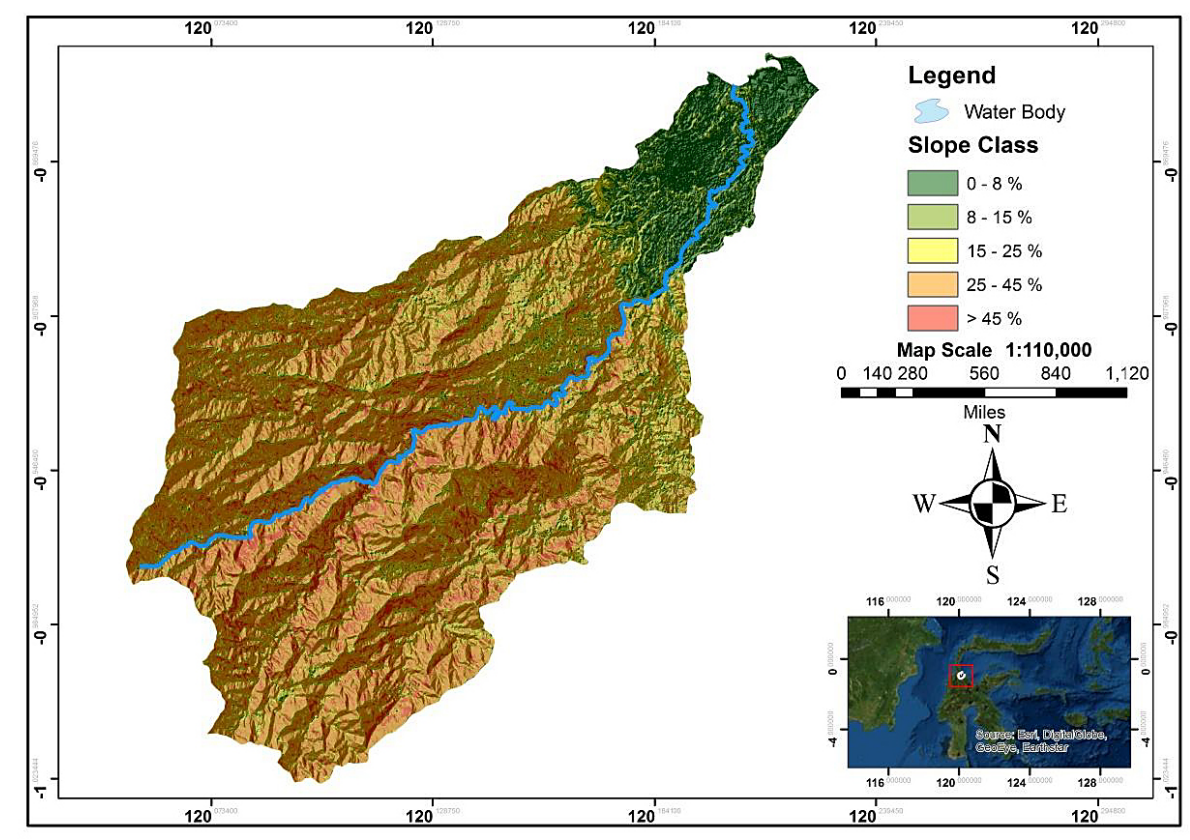

Figure 3. LS factor

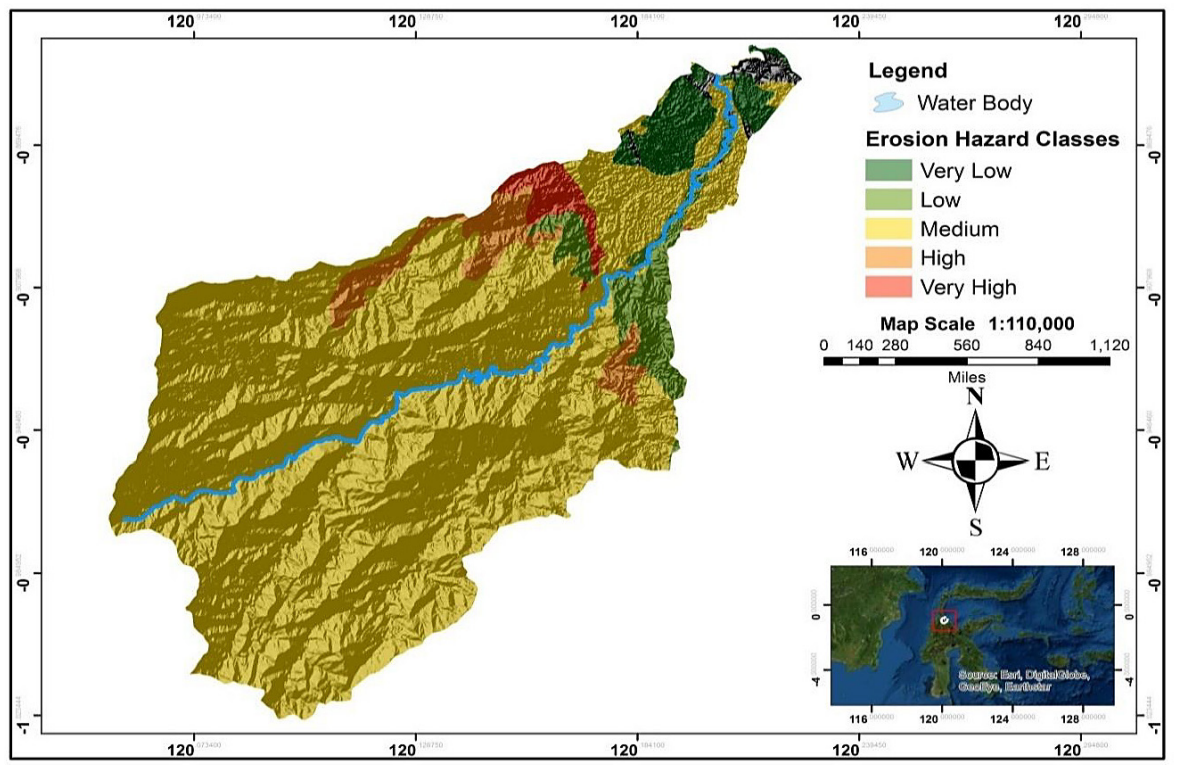

Figure 4. Erosion hazard classes 
Figure 4, shows that dry agricultural land has a very high erosion hazard due to the high range of C and LS values, where these factors cause high RUSLE results because the $\mathrm{R}$ and $\mathrm{K}$ factors are only characterized by slight differences in the study area. According to Eisenberg and Muvundja, (2020) the sand content causes a low K factor and reduces erosion due to high infiltration due to vacuum. According to Srinivasan et al., (2019), if the higher organic matter content usually reduces the susceptibility to erosion, this can be found in primary and Secondary Land Forest areas in the Dolago watershed.

\section{CONCLUSIONS}

The corrosion hazard classification in the Dolago Watershed varies, including very low, low, medium, high, and very high. Dryland agriculture had a very high erosion rate of $577.95 \mathrm{t} / \mathrm{ha} / \mathrm{yr}$. A very low erosion rate was found in a rice field of $2.22 \mathrm{t} / \mathrm{ha} / \mathrm{yr}$.

Most of the Dolago watershed areas were included in the medium erosion hazard classification mainly in primary and secondary land forests, while the areas included in the high erosion hazard classification were concentrated in the Dolago watershed because of the high slope length and steepness values (LS-Factor).

In the study area, a combination of mechanical and vegetative soil and water conservation methods is needed to minimize the erosion rate by increasing soil stabilization and vegetation density. It is recommended that model validation and testing should be carried out in future studies, as this is a strategic step to develop a more effective and efficient sediment yield modeling tool. The results obtained can help in the application of soil management and conservation practices to reduce the soil loss in the Dolago watershed.

\section{REFERENCES}

1. Abdulkadir, T. S., Mustafa, M. R., Yusof, K. W., Hashim, A. M. 2016. Evaluation of rainfall-runoff erosivity factor for Cameron Highlands, Pahang, Malaysia. Journal of Ecological Engineering, 17(3), 20-25.

2. Abood, S. A., Lee, J. S. H., Burivalova, Z., GarciaUlloa, J., Koh, L. P. 2015. Relative contributions of the logging, fiber, oil palm, and mining industries to forest loss in Indonesia. Conservation Letters, 8(1), 58-67.
3. Adimassu, Z., Langan, S., Johnston, R., Mekuria, W., Amede, T. 2017. Impacts of soil and water conservation practices on crop yield, run-off, soil loss and nutrient loss in Ethiopia: review and synthesis. Environmental management, 59(1), 87-101.

4. Alatorre, L. C., Beguería, S., Lana-Renault, N., Navas, A., García-Ruiz, J. M. 2012. Soil erosion and sediment delivery in a mountain catchment under scenarios of land use change using a spatially distributed numerical model. Hydrology and Earth System Sciences, 16(5), 1321-1334.

5. Arsyad, S. 2010. Soil and water conservation. Bogor.

6. Asiedu, J. K. 2018. Assessing the Threat of Erosion to Nature-Based Interventions for Stormwater Management and Flood Control in the Greater Accra Metropolitan Area, Ghana. Journal of Ecological Engineering, 19(1), 1-13.

7. Biddoccu, M., Guzmán, G., Capello, G., Thielke, T., Strauss, P., Winter, S., Gómez, J. A. 2020. Evaluation of soil erosion risk and identification of soil cover and management factor (C) for RUSLE in European vineyards with different soil management. International Soil and Water Conservation Research, 8(4), 337-353.

8. Borrelli, P., Robinson, D. A., Fleischer, L. R., Lugato, E., Ballabio, C., Alewell, C., Panagos, P. 2017. An assessment of the global impact of 21 st century land use change on soil erosion. Nature communications, 8(1), 1-13.

9. Chen, D., Wei, W., Chen, L. 2017. Effects of terracing practices on water erosion control in China: A meta-analysis. Earth-Science Reviews, 173, 109-121.

10. Chuenchum, P., Xu, M., Tang, W. 2020. Estimation of soil erosion and sediment yield in the Lancang-Mekong river using the modified revised universal soil loss equation and GIS techniques. Water, 12(1), 135.

11. De Mello, K., Valente, R. A., Randhir, T. O., Vettorazzi, C. A. 2018. Impacts of tropical forest cover on water quality in agricultural watersheds in southeastern Brazil. Ecological Indicators, 93, 1293-1301.

12. Eisenberg, J., Muvundja, F. A. 2020. Quantification of Erosion in Selected Catchment Areas of the Ruzizi River (DRC) Using the (R) USLE Model. Land, 9(4), 125.

13. Ganasri, B. P., Ramesh, H. 2016. Assessment of soil erosion by RUSLE model using remote sensing and GIS-A case study of Nethravathi Basin. Geoscience Frontiers, 7(6), 953-961.

14. Gelagay, H. S., Minale, A. S. 2016. Soil loss estimation using GIS and Remote sensing techniques: A case of Koga watershed, Northwestern Ethiopia. International Soil and Water Conservation Research, 4(2), 126-136. 
15. Giacomazzo, M., Bertolo, A., Brodeur, P., Massicotte, P., Goyette, J. O., Magnan, P. 2020. Linking fisheries to land use: How anthropogenic inputs from the watershed shape fish habitat quality. Science of The Total Environment, 717, 135377.

16. Gomiero, T. 2016. Soil degradation, land scarcity and food security: Reviewing a complex challenge. Sustainability, 8(3), 281.

17. Haghighi, A. T., Darabi, H., Karimidastenaei, Z., Davudirad, A. A., Rouzbeh, S., Rahmati, O., Klöve, B. 2021. Land degradation risk mapping using topographic, human-induced, and geo-environmental variables and machine learning algorithms, for the Pole-Doab watershed, Iran. Environmental Earth Sciences, 80(1), 1-21.

18. Haregeweyn, N., Tsunekawa, A., Nyssen, J., Poesen, J., Tsubo, M., Tsegaye Meshesha, D., Tegegne, F. 2015. Soil erosion and conservation in Ethiopia: a review. Progress in Physical Geography, 39(6), 750-774.

19. Harjianto, M., Sinukaban, N., Tarigan, S. D., Haridjaja, O. 2016. Land Capability Evaluation for Land Use Recommendation in Lawo Watershed. Jurnal Penelitian Kehutanan Wallacea, 5(1), 1-11.

20. Hurni, H. 1985 Erosion-Productivity Conservation Systems in Ethiopia. 4th ISCO Conference, Venezuala, 654-674.

21. Jin, F., Yang, W., Fu, J., Li, Z. 2021. Effects of vegetation and climate on the changes of soil erosion in the Loess Plateau of China. Science of The Total Environment, 773, 145514.

22. Kalambukattu, J., Kumar, S. 2017. Modelling soil erosion risk in a mountainous watershed of Mid-Himalaya by integrating RUSLE model with GIS. Eurasian Journal of Soil Science, 6(2), 92-105.

23. Li, X., Cheng, G., Ge, Y., Li, H., Han, F., Hu, X., Cai, X. 2018. Hydrological cycle in the Heihe River Basin and its implication for water resource management in endorheic basins. Journal of Geophysical Research: Atmospheres, 123(2), 890-914.

24. Mehri, A., Salmanmahiny, A., Tabrizi, A. R. M., Mirkarimi, S. H., Sadoddin, A. 2018. Investigation of likely effects of land use planning on reduction of soil erosion rate in river basins: Case study of the Gharesoo River Basin. Catena, 167, 116-129.

25. Mohamed, E. S., Schütt, B., Belal, A. 2013. Assessment of environmental hazards in the north western coast-Egypt using RS and GIS. The Egyptian Journal of Remote Sensing and Space Science, 16(2), 219-229.

26. Mohammad, A. G., Adam, M. A. 2010. The impact of vegetative cover type on runoff and soil erosion under different land uses. Catena, 81(2), 97-103.

27. Naharuddin, N., Malik, A., Rachman, I., Muis, H., Hamzari, H., Wahid, A. 2020. Land Use Planning for Post-Disaster Soil Liquefaction Area Based on Erosion Hazard Index. International Journal of design \& Nature of ecodynamics, 15(4), 573-578.

28. Naharuddin, Wahid, A., Rukmi, Sustri 2019. Erosion Hazard Assessment in Forest and Land Rehabilitation for Managing the Tambun Watershed in Sulawesi, Indonesia. Journal of Chinese Soil and Water Conservation, 50(3), 124-130.

29. Ouyang, W., Wu, Y., Hao, Z., Zhang, Q., Bu, Q., Gao, X. 2018. Combined impacts of land use and soil property changes on soil erosion in a mollisol area under long-term agricultural development. Science of the total environment, 613, 798-809.

30. Özşahin, E., Eroğlu, İ. 2019. Soil Erosion Risk Assessment due to Land Use/Cover Changes (LUCC) in Bulgaria from 1990 to 2015. Alınteri Zirai Bilimler Dergisi, 34(1), 1-8.

31. Panagos, P., Standardi, G., Borrelli, P., Lugato, E., Montanarella, L., Bosello, F. 2018. Cost of agricultural productivity loss due to soil erosion in the European Union: From direct cost evaluation approaches to the use of macroeconomic models. Land Degradation \& Development, 29(3), 471-484.

32. Phinzi, K., Ngetar, N. S., Ebhuoma, O. 2021. Soil erosion risk assessment in the Umzintlava catchment (T32E), Eastern Cape, South Africa, using RUSLE and random forest algorithm. South African Geographical Journal, 103(2), 139-162.

33. Poesen, J. 2018. Soil erosion in the Anthropocene: Research needs. Earth Surface Processes and Landforms, 43(1), 64-84.

34. Pradhan, B., Chaudhari, A., Adinarayana, J., Buchroithner, M. F. 2012. Soil erosion assessment and its correlation with landslide events using remote sensing data and GIS: a case study at Penang Island, Malaysia. Environmental monitoring and assessment, 184(2), 715-727.

35. Rybicki, R. 2021. Environmental Effects of Reducing Land Fragmentation in Land Consolidation at West Roztocze at the Slope Scale. Journal of Ecological Engineering, 22(1), 240-248.

36. Sharma, A., Tiwari, K. N., Bhadoria, P. B. S. 2011. Effect of land use land cover change on soil erosion potential in an agricultural watershed. Environmental monitoring and assessment, 173(1), 789-801.

37. Siddique, M. N. A., Sultana, J., Abdullah, M. R., Azad, K. N. 2017. Modelling of Soil Loss through RUSLE2 for Soil Management in an Agricultural Field of Uccle, Belgium. British Journal of Environment \& Climate Change, 7(4), 252-260.

38. Silalahi, R. R., Supriadi, S. S., Razali, R. R. 2017. Mapping Erosion Level in Petani Sub Watershed North Sumatera. Agroekoteknologi Universitas Sumatera Utara, 5(1), 109613.

39. Sokouti, R., Nikkami, D. 2017. Optimizing land use 
pattern to reduce soil erosion. Eurasian Journal of Soil Science, 6(1), 75-83.

40. Srinivasan, R., Singh, S. K., Nayak, D. C., Hegde, R., Ramesh, M. 2019. Estimation of soil loss by USLE model using remote sensing and GIS Techniques-A case study of Coastal Odisha, India. Eurasian Journal of Soil Science, 8(4), 321-328.

41. Sun, W., Shao, Q., Liu, J. 2013. Soil erosion and its response to the changes of precipitation and vegetation cover on the Loess Plateau. Journal of Geographical Sciences, 23(6), 1091-1106.

42. Tarigan, S., Wiegand, K., Slamet, B. 2018. Minimum forest cover required for sustainable water flow regulation of a watershed: a case study in Jambi Province, Indonesia. Hydrology \& Earth System Sciences, 22(1).

43. Teng, M., Huang, C., Wang, P., Zeng, L., Zhou, Z., Xiao, W., Liu, C. 2019. Impacts of forest restoration on soil erosion in the Three Gorges Reservoir area, China. Science of the Total Environment, 697, 134164.

44. Tesfaye, G., Debebe, Y., Fikirie, K. 2018. Soil erosion risk assessment using GIS based USLE model for soil and water conservation planning in Somodo watershed, south West Ethiopia. IJOEAR, 4, 35-43.

45. Tessema, Y. M., Jasińska, J., Yadeta, L. T., Świtoniak, M., Puchałka, R., Gebregeorgis, E. G.
2020. Soil loss estimation for conservation planning in the welmel watershed of the Genale Dawa Basin, Ethiopia. Agronomy, 10(6), 777.

46. Watene, G., Yu, L., Nie, Y., Zhu, J., Ngigi, T., Nambajimana, J. D. D., Kenduiywo, B. 2021. Water Erosion Risk Assessment in the Kenya Great Rift Valley Region. Sustainability, 13(2), 844.

47. Wischmeier, W. H. 1978. Predicting rainfall erosion losses-A guide to conservation planning. paper, (537), 1-69.

48. Wischmeier, W. H., Smith, D. D. 1978. Predicting rainfall erosion losses. Agricultural Handbook 537. Agricultural Research Service, United States Department of Agriculture.

49. Zare, M., Panagopoulos, T., Loures, L. 2017. Simulating the impacts of future land use change on soil erosion in the Kasilian watershed, Iran. Land Use Policy, 67, 558-572.

50. Zhang, M., Liu, N., Harper, R., Li, Q., Liu, K., Wei, X., Liu, S. 2017. A global review on hydrological responses to forest change across multiple spatial scales: Importance of scale, climate, forest type and hydrological regime. Journal of Hydrology, 546, 44-59.

51. Zokaib, S., Naser, G. 2011. Impacts of land uses on runoff and soil erosion A case study in Hilkot watershed Pakistan. International Journal of Sediment Research, 26(3), 343-352. 